\title{
NAT2*14 Allele
}

National Cancer Institute

\section{Source}

National Cancer Institute. NAT2*14 Allele. NCI Thesaurus. Code C67346.

Human NAT $2 * 14$ allele is a designation for a group of variant alleles of the NAT 2 gene, which is located in the vicinity of $8 p 22$ and is approximately $10 \mathrm{~kb}$ in length. The wild-type allele, which encodes arylamine $\mathrm{N}$-acetyltransferase 2 protein, is involved in the activation/deactivation of arylamine and hydrazine compounds. This group of allelic variants of the NAT 2 gene all exhibit a SNP (c. 191G>A) that results in a R64Q coding change and is associated with decreased enzymatic activity of the encoded protein. 